STUDIA EDUKACYJNE NR 31/2014

NeBOJSA PAVLOVIC

Vrnjacka Banja

Serbia

\title{
EFFECTS OF GENDER DIFFERENCES ON LEADERSHIP STYLES THROUGH THE IMPACT ON SCHOOL ENVIRONMENT
}

\begin{abstract}
Pavlovic Nebojsa, Effects of Gender Differences on Leadership Styles Through the Impact on School Environment [Wpływ różnic płci na style przywództwa w środowisku szkolnym]. Studia Edukacyjne nr 31, 2014, Poznań 2014, pp. 305-322. Adam Mickiewicz University Press. ISBN 978-83-2322781-6. ISSN 1233-6688

This paper deals with the problem of existence of differences between women and men regarding management style in the school. The aim of this quantitative study was to determine whether there are differences in the management style in the school regarding gender of the school principal. The sample included 35 randomly chosen school principals in Serbia. The research obtained results according to which the gender of the school principal does not affect his/her working style and orientation toward people and tasks.
\end{abstract}

Key words: school principal style, gender, principal oriented to concern for people, principal oriented to concern for tasks

\section{Introduction}

Educational institutions are the place where people play most important role in providing of organizational efficiency and effectivity.This creates an issue because of widespread role of women in school management: Are female management styles different from men management styles? This question extrudes second question: Are women more or less efficient than men playing these roles?

There are different opinions about differences between men and women in management roles. First, the management is biologically specified for men. Second, the role of socialization is essential for the creation of differences between genders. Third concept explains the environment as a deter- 
minant for defining of differences. Fourth perspective accepts differences between men and women, in order to understand and articulate them in the right way. ${ }^{1}$

The selection of management style which will be efficient for school management is more important for a principal rather than the difference between genders.

\section{Problem of Research}

The study starts from the fact that leaders in educational institutions are same as leaders in other organizations. The research according to use of authority or transformational leadership style was not applied. Instead, twodimensional matrix with coordination including concern for people and tasks was chosen. It was known as managerial system. ${ }^{2}$ This system offers the entire sequence of styles and possibilities. Head can move within the network, so his/her commitment to jobs or people is visible. The advantage of the managerial system lies in the fact that principal can adapt his/her style to a particular situation in the school. In order to be efficient, he/she needs to maintain attention for people and tasks. The emphasis of this system is placed on a team leadership.

Theoretical importance of the research is reflected in better knowledge about the influence of the gender on leadership style. The knowledge that the principal can use (while accepting of this work and selecting the working style) in the school is useful for practice.

The study included only management style, which can create limitations, so further researches are supported. Above all, the research about efficiency of work of the school principal regarding the gender is recommended.

\section{Research Focus}

Methodological obstacles and domination of male researchers who mostly were interested in scientific assumption about genders equality in leadership have led to ignorance of issues regarded to genders until ' $70 \mathrm{~s}^{3}$

1S. Appelbaum, L. Audet, J. Miller, Gender and Leadership? Leadership and Gender? A Journey Through The Landscape of Theories, Leadership and Organization Development Journal, 2003, 24, 1, p.43-51.

2 R. Blake, J. Mouton, The Manogerial Grid III, Houston, 1985.

3 M.M. Chemers, C.B. Watson, S.T. May, Dispositional affect and leadership effectiveness: a comparison of self-esteem, optimism, and efficacy, Personality and Social Psychology Bulletin, 2000, 26 (3), p. 267-277. 
Researches on differences between men and women who engaged in managerial positions can offer two basic theories. One of them minimizes and ignores differences between genders while the other tries to proof their existence. ${ }^{4}$

Researchers express many differences regarding their points of view. Olid argues that women have a lack of skills and competencies needed to succeed in management. ${ }^{5}$ Other researchers enhance the superiority of women on leadership positions. ${ }^{6}$ There is a group of researchers who claim that there may be a weak or none connection between genders and leadership styles, including energy. ${ }^{7}$ Eagly (2005) used meta-analysis to confirm that, despite stereotypes, women in leadership have the same working style as men - leaders. Also, women have good balanced orientations regarding working style: they are equally oriented to relationships and tasks. The second meta-analysis showed similar results. ${ }^{8}$ Another group includes researchers who claim that there are small differences in leadership styles and ability regarding men and women as leaders. Women have slight limitations in efficiency while playing male roles traditionally while traditionally female roles give them certain advantages. Furthermore, women use more democratic or participative styles than men, and they perform transformational leadership and component of potential reward. According to that, they present styles aligned with modern argues about effective leadership. ${ }^{9}$

Researchers discovered that women are underestimated rather than men in cases where they expressed male leadership style. ${ }^{10}$ In other words, they were underestimated while playing male roles such as sports coach or manager in production facilities typically. ${ }^{11}$ Evaluators in these cases were men.

${ }^{4}$ G. Powell, L. Graves, Vomen and men in management, Thousand Oaks 2003.

5 C. Olid, Models of Professional Career of the Managerial Woman, Universitas Psychologica, 2013, 12 (4), p. 1237-1254. Doi: 10.11144/Javeriana.UPSY12-4.mopc

${ }^{6}$ E. Book, Why the best man for the job is a woman, Harper Collins, New York 2000; R.O. De Zárate, Women rulers currently in office, 2007, from http://www.terra.es/ personal2/ monolith/00women5.htm [retrieved: 20.07.2014].

7 M. Engen, R. Leeden, T. Willemsen, Gender, context and leadership styles: A field study, Journal of Occupational and Organizational Psychology, 2001, 74, p. 581-598; Kennard J., The differences between male and female, 2012 from: http://www.trainingzone.co.uk/user/85621 [retrieved: 20.07.2014].

8 A. Eagly, I. Carli, The female leadership advantage: An evaluation of the evidence, Leadership Quarterly, 2003, 14, p. 807-834.

9 P. Northouse, Liderstvo teorija i praksa, Beograd 2008.

10 M. Warrell, Can Women Do More To Make Their Way To The top? 2011, from: www.forbes.com/... /womensmedia/.../can-women [retrieved: 20.07.2014].

${ }_{11} \mathrm{H}$. Taniguchi, Gender Differences in the Effect of Employment and Family Characteristics, Nonprofit and Voluntary Sector Quarterly, 2006, 35, 1, p. 83-101. 
The reason for different research results lies in differences in methodology and way of data collecting. According to Engen, there are three typical problems in literature. These problems are related to differences between sexes in leadership styles. ${ }^{12}$ First problem presents conclusions about women defined in studies by women themselves..$^{13}$ Second problem lies in "strong conclusions" which comes from the fact that there are large differences in genders, regarding leadership style to conclusions which deny the existence of any differences between men and women. ${ }^{14}$ Third problem presents confusion because of the presence of other variables needed for explanation of differences between genders (power, hierarchical levels, organizational type etc.). ${ }^{15}$ Veccio claims that differences between genders should be an advantage rather than to place at least one of them in an unfavorable position. ${ }^{16}$

According to Northouse, leadership is a process in which an individual controls to the group in order to achieve a common goal. ${ }^{17}$ Because of the process, the group influences on leader. Leaders and their followers are part of the leadership, so they always need to be analyzed regarding relationships.

By accessing the leader's style, the way how leader treats others and how they can change their behaviour can be defined. The purpose of this is to make their behaviour more efficient. ${ }^{18}$

Managerial network which was used in the research appeared in early '60s, and it was updated several times. ${ }^{19}$ It was organized in a way to explain in which way managers help organizations to fulfil their purpose by using two factors: concern for tasks and concern for people. Concern for tasks is related to the way how leader conducts organizational tasks while concern for people defines a way how leader treats employees in the organization who attend to achieve its goals. ${ }^{20}$ 2000.

12 M. Engen, T. Willemsen, Gender and leadership styles: a review of the post decade, Tilburg

13 C. Hymowitz, In the lead: Women tell women: Life in the top jobs is worth the effort, Wall Street Journal, 2006, November 20, B1.

14 A. Eagly, Achieving relational authenticity in leadership: Does gender matter? Leadership Quarterly, 2005, 16, p. 459-474.

15 T. Judge et al., Personality and leadership: A qualitative and quantitative review, Journal of Applied Psychology, 2002, 87, p. 765-780.

16 R. Veccio, Leadership and gender advantage, Leadership Quarterly, 2002, 13, p. 643-671.

${ }^{17}$ P. Northouse, Liderstvo teorija i praksa.

18 Ibidem.

${ }_{19}$ R. Blake, A. McCanse, Leadership dilemmas: Grid solution, Houston 1991; R. Blake, J. Mouton, The Managerial Grid, Houston 1964; R. Blake, J. Mouton, The new managerial Grid, Houston 1978; R. Blake, J. Mouton, The Managerial Grid III, Houston 1985.

${ }^{20}$ P. Northouse, Liderstvo teorija i praksa. 
Managerial network connects concern for tasks and concern for people in a model which includes two intersecting axes. Horizontal axis presents leader's concern for tasks while vertical axis presents concern for people. Each axis contains scale with nine points, of which one shows minimum and nine presents maximum interest. By connecting these results of each of axes, different leadership styles can be shown. ${ }^{21}$ According to Northouse, leader's network includes five common leadership styles: Authority-compliance $(9,1)$, Country club management $(1,9)$, Impoverished management $(1,1)$, Middle of the road management $(5,5)$ and Team management $(9,9)$ :

- Authority-compliance $(9,1)$. This leadership style includes enhance of tasks and weaker enhance of role of people.This leader likes control; he/she is demanding and authoritative.

- Country club management $(1,9)$. This style includes weak concern for tasks while there is a considerable concern for human relationships. These leaders create a positive atmosphere; they are cooperative and ready to help.

- Impoverished management $(1,1)$. It represents a leader who does not care about tasks or human relationships. Leader with this style is uninterested, uncommitted and reluctant.

- Middle of the road management $(5,5)$. Leaders are ready for compromise. They are moderately interested in tasks and people. They want to find a balance in concern for people and tasks. This leader mitigates disagreements and prefers medium solutions.

- Team management $(9,9)$. In this case, concern for people and tasks are enhanced. High level of participation and teamwork are promoted. ${ }^{22}$

There is no consensus about finding the best style of leadership. Some researchers suggest that managers with highly expressed concern for people and tasks are most useful (Northouse, 2008). Other showed that there is no total connection between maximum results and affectivity in all situations. ${ }^{23}$

\section{Methodology of Research}

General Backround of Research. The main aim of the research is following: to determine whether there is a statistically meaningful connection between school-principal's orientation toward people and tasks and gender of the school principal. Specific goals are following: a) To determine whether there is a statistically important difference in orientation of the school prin-

\footnotetext{
${ }^{21}$ Ibidem.

22 Ibidem.

${ }^{23}$ P. Robbins, M. Coutler, Management, Belgrade 2005.
} 
cipal toward people and his/her gender and b) To determine whether there is a statistically important difference in orientation of the school principal toward tasks and his/her gender.

This work started with defined problem: To what extent differences between men and women are expressed in the selection of style of the school principal. Particular problems were following: a) To which extent there is a difference between genders in orientation of the school principal toward people and b) To which extent there is a difference between genders in orientation of the school principal toward tasks.

\section{Research problem}

1. There is a statistically meaningful difference in measurement of style of principals within two groups: men and women.

2. There is a statistically meaningful difference in measurement of style of principal - orientation toward people within two groups: men and women;

3. There is a statistically meaningful difference in measurement of style of orientation toward tasks within two groups: men and women.

Sample of Research. The independent variable in this work represents gender of the school principal: male and female. According to this, two kinds of school principals are included: a) male school principals and b) female school principals.

Dependent variable represents the style of the school principal. Principals are divided into two groups, according to their orientations in working style: a) principal oriented to concern for people and b) principal oriented to concern for tasks.

\section{Instrument and procedures}

The research used Blake instrument in order to explore the behaviour of the school principal. This instrument is known as managerial network by Blake \& Mouton. ${ }^{24}$ The instrument included 18 questions with Likert scale (five claims). Nine of these questions are related to orientation toward people (y-axis), and other nine questions are related to orientation toward tasks (x-axis). Reliability of the instrument was determined by using of Cronbach's

\footnotetext{
${ }^{24}$ P. Northouse, Liderstvo teorija i praksa.
} 
Alpha coefficient, and it had value of 0,86 which proves magnificent reliability and internal compliance of the scale, regarding this sample (Tab. 1).

Table 1

Cronbach's Alpha

\begin{tabular}{|c|c|c|}
\hline Cronbach's Alpha & Cronbach's AB Std Items & N of Items \\
\hline, 846 &, 859 & 18 \\
\hline
\end{tabular}

Data Analysis. Data processing was made using following procedures: a) descriptive statistics (arithmetic mean and standard deviation) to determine the severity of essential research variables and b) for comparison of mean values of marks defined in two different groups, parameter t-test for independent samples was used.

All statistical analyses were made by using of statistical package software SPSS 21.0 (Statistical Package for the Social Sciences for Windows).

\section{Results of Research}

The sample structure includes 35-school principals who engaged in research. 19 of them are men while the other 16-school principals are women.

All determinants of the school principal style and his/her orientations are relatively highly expressed. At the scale from 1 to 5 , all of them were over 3 . Respondents gave highest grades in answers related with teams $(\mathrm{M}=4,57$ and $\mathrm{M}=4,42 ;$ Tab. 2$)$ and commitment to fulfil a task $(\mathrm{M}=4,45$; Tab. 2). It should be kept in mind that it is not a great difference between the highest ( $M=4,57$ for the team encouraging, and the lowest mark, $M=3,48$; Tab. 2) which is connected with the concern of the principal not to hurt employee with his/her critics.

The average orientation of male principals toward people is $M=7.23$ and $M=7,10$ for woman's principals (Tab. 3 ) which is also a very small difference. Within the orientation to tasks, $M=7,21$ is a point for men and $M=7,16$ is a mark for women (Tab. 3), which also shows a little difference. It can be argued that male and female principals are equally oriented toward people and tasks.

For comparison of values of the mark measured in two different groups, Parameter independent sample T-test was used (independent sample t-test; Tab. 4). This test shows if there is a statistically important difference in average score of orientation toward people and tasks, within two groups (male and female in this case). 
Table 2

Descriptive Statistics: Orientation of the people

\begin{tabular}{|c|c|c|c|c|c|c|}
\hline \multirow{2}{*}{\multicolumn{2}{|c|}{ You mark your gender: }} & \multirow{2}{*}{$\frac{N}{35}$} & \multirow{2}{*}{$\frac{\operatorname{Min}}{1.00}$} & \multirow{2}{*}{$\frac{\operatorname{Max}}{2.00}$} & \multirow{2}{*}{$\begin{array}{l}\text { Mean } \\
1.457\end{array}$} & \multirow{2}{*}{$\begin{array}{c}\mathrm{SD} \\
.5054\end{array}$} \\
\hline & & & & & & \\
\hline 1. & $\begin{array}{l}\text { I encourage my team to participate } \\
\text { when it comes decision making time } \\
\text { and I try to implement their ideas and } \\
\text { suggestions }\end{array}$ & 35 & 1.00 & 5.00 & 4.5714 & .77784 \\
\hline 2. & $\begin{array}{l}\text { Nothing is more important than ac- } \\
\text { complishing a goal or task }\end{array}$ & 35 & 1.00 & 5.00 & 3.5143 & 1.26889 \\
\hline 3. & $\begin{array}{l}\text { I closely monitor the schedule to ensure } \\
\text { a task or project will be completed in } \\
\text { time }\end{array}$ & 35 & 2.00 & 5.00 & 4.1143 & .79600 \\
\hline 4. & $\begin{array}{l}\text { I enjoy coaching people on new tasks } \\
\text { and procedures }\end{array}$ & 35 & 1.00 & 5.00 & 3.5714 & .97877 \\
\hline 5. & $\begin{array}{l}\text { The more challenging a task is, the } \\
\text { more I enjoy it }\end{array}$ & 35 & 1.00 & 5.00 & 3.9714 & 1.09774 \\
\hline 6. & $\begin{array}{l}\text { I encourage my employees to be crea- } \\
\text { tive about their job }\end{array}$ & 35 & 1.00 & 5.00 & 4.2857 & 1.04520 \\
\hline 7. & $\begin{array}{l}\text { When seeing a complex task through to } \\
\text { completion, I ensure that every detail is } \\
\text { accounted for }\end{array}$ & 35 & 2.00 & 5.00 & 4.4571 & .74134 \\
\hline 8. & $\begin{array}{l}\text { I find it easy to carry out several com- } \\
\text { plicated tasks at the same time }\end{array}$ & 35 & 2.00 & 5.00 & 4.0571 & .80231 \\
\hline 9. & $\begin{array}{l}\text { I enjoy reading articles, books, and } \\
\text { journals about training, leadership and } \\
\text { psychology and then putting what I } \\
\text { have read into action }\end{array}$ & 35 & 2.00 & 5.00 & 3.4857 & 1.01087 \\
\hline 10. & $\begin{array}{l}\text { When correcting mistakes, I do not } \\
\text { worry about jeopardizing relationships }\end{array}$ & 35 & 1.00 & 5.00 & 3.4857 & 1.03955 \\
\hline 11. & I manage my time very efficiently & 35 & 2.00 & 5.00 & 4.0000 & .76696 \\
\hline 12. & $\begin{array}{l}\text { I enjoy explaining the intricacies and } \\
\text { details of a complex task or project to } \\
\text { my employees }\end{array}$ & 35 & 1.00 & 5.00 & 3.5429 & 1.06668 \\
\hline 13. & I manage my time very efficiently & 35 & 2.00 & 5.00 & 4.0286 & .85700 \\
\hline 14. & $\begin{array}{l}\text { Nothing is more important than build- } \\
\text { ing a great team }\end{array}$ & 35 & 2.00 & 5.00 & 4.4286 & .77784 \\
\hline 15. & I enjoy analyzing problems & 35 & 2.00 & 5.00 & 3.8857 & .90005 \\
\hline 16. & I honor other people's boundaries & 35 & 2.00 & 5.00 & 4.2000 & .79705 \\
\hline 17. & $\begin{array}{l}\text { Counseling my employees to improve } \\
\text { their performance or behavior is second } \\
\text { nature to me }\end{array}$ & 35 & 2.00 & 5.00 & 4.4280 & .82503 \\
\hline 18. & $\begin{array}{l}\text { I enjoy reading articles, books, and } \\
\text { trade journals about my profession; and } \\
\text { then implementing the new procedures } \\
\text { I have learned }\end{array}$ & 35 & 2.00 & 5.00 & 3.9143 & .85307 \\
\hline
\end{tabular}




\begin{tabular}{|c|l|c|c|c|c|c|}
\hline \multicolumn{2}{|c|}{ You mark your gender: } & N & Min & Max & Mean & SD \\
\cline { 3 - 7 } & 35 & 1.00 & 2.00 & 1.457 & .5054 \\
\hline 19. & Orientation of the people & 35 & 4.00 & 8.40 & 7.1714 & .93952 \\
\hline 20. & Orientation to task & 35 & 4.00 & 8.80 & 7.1886 & .92665 \\
\hline 21. & Valid N (listwise) & 35 & & & & \\
\hline
\end{tabular}

In Table 4 the dimension named as Independent Samples Test Sig. (Levine Test for Equality of Variances) is for orientation toward people larger than $0,05(0,078)$ which focuses us to read data from the line of equal variances (Equal variances assumed).

In Table 4 the dimension named as Independent Samples Test Sig. (Levine Test for Equality of Variances) is for orientation toward tasks smaller than $0,05(0,01)$ which focuses us to read data from the second line of unequal variances (Equal variances not assumed).

Since the column Sig. (2-tailed, Tab. 4) has the result 0.686 (which is above 0,05 ) it is concluded that the difference between two groups (men and women) regarding orientation to people is not significant but accident.

Table 3

Group Statistics

\begin{tabular}{|l|c|c|c|c|c|}
\hline & Gender & $\mathrm{N}$ & Mean & SD & Std.E.m \\
\hline $\begin{array}{l}\text { Orientation } \\
\text { of the peo- } \\
\text { ple }\end{array}$ & $\mathrm{M}$ & 19 & 7.2316 & 1.14749 & .26325 \\
\cline { 2 - 6 } & $\mathrm{F}$ & 16 & 7.1000 & .64083 & .16021 \\
\hline $\begin{array}{l}\text { Orientation } \\
\text { to task }\end{array}$ & $\mathrm{M}$ & 19 & 7.2105 & 1.18223 & .27122 \\
\cline { 2 - 6 } & $\mathrm{F}$ & 16 & 7.1625 & .51753 & .12938 \\
\hline
\end{tabular}

In the orientation to tasks Sig. (2-tailed; Tab. 4) the mark from the second line is 0.874 (also above 0,05 ) so it is concluded that the difference between male and female group is also not significant but accident.

Indicators of the effect size for the size of differences between groups were measured by Eta square which can be calculated in following way:

$$
t^{2} / t^{2}+(N-2)
$$

Obtained results for both orientations are less than 0,005. It is concluded that according this size, differences between two groups (male and female) are very small: $0,01=$ small influence; $0,06=$ moderate influence and $0,014=$ great influence. 
$\frac{\pi}{4}$

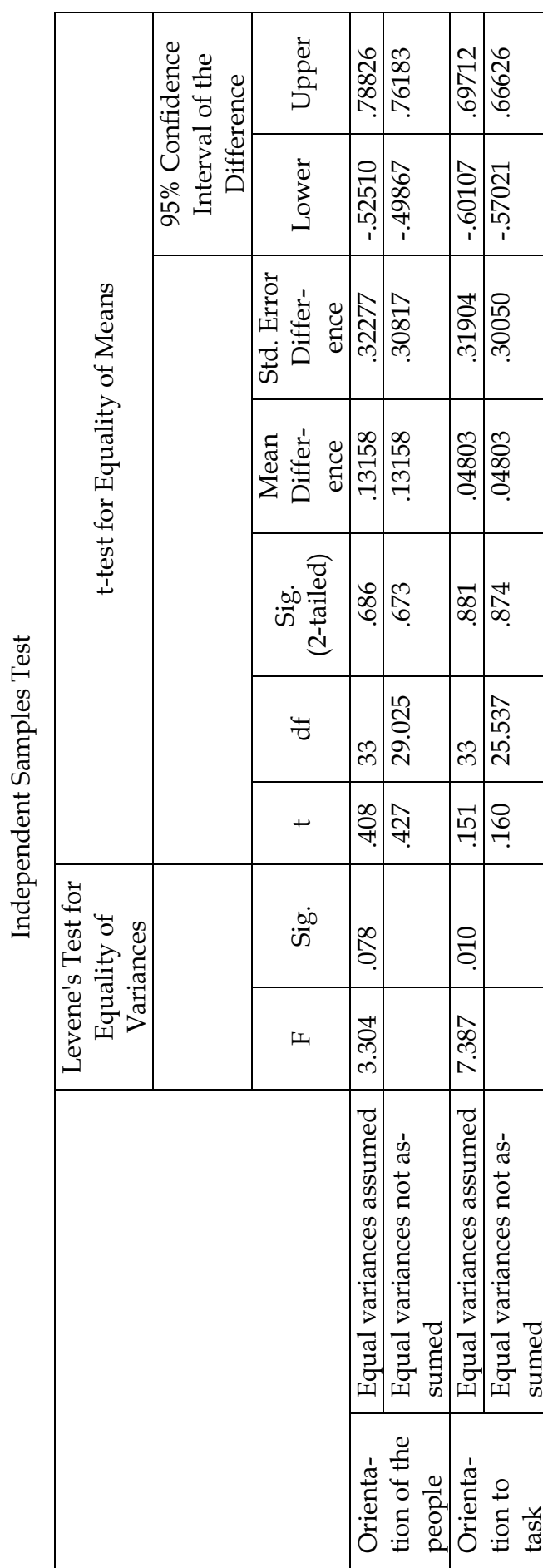

$\frac{0}{\pi}$ (2)

שี

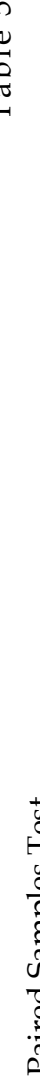

离

ڤิ م)

\begin{tabular}{|c|}
\hline$\widetilde{T}$ \\
\hline+ \\
\hline $\bar{\pi}$ \\
\hline
\end{tabular}

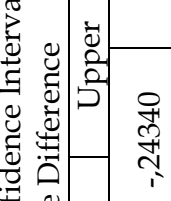
(당

نे

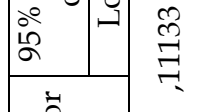
究 đ

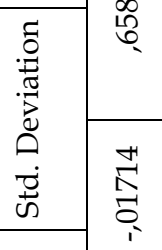

절

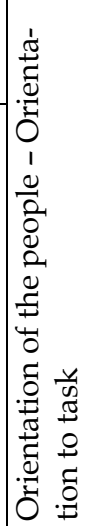


It is concluded that the T-test of independent samples was used for comparison of results of testing of two orientations of the leadership style, within two groups, male and female.

There was no significant difference between results for men $(M=7,23$; $\mathrm{SD}=1,14$ ) or women $\mathrm{M}=7,10 ; \mathrm{SD}=0,640$ regarding orientation to people (Tab. 3). Results $\mathrm{t}$ (33) $p=0.7$ (mutually). The difference between mean values of marks by groups (average difference $=0.13 ; 95 \%$ CI: $-0,52$ to 0,78 ) was very small (eta square $-\eta 2=0,005$ ).

There was no significant difference in results for men $(M=7,21$; $S D=1,18)$ or women $\mathrm{M}=7 ; 16, \mathrm{SD}=0,517)$ regarding orientation to tasks. Results $\mathrm{t}$ (25 537), $p=0.9$ (mutually). The difference between mean values of marks by groups (average difference $=0.048 ; 95 \%$ CI: $-0,57$ to 0,66 ) was very small (eta square $-\eta 2=0,005)$.

Using Paired Samples T-test, we measured differences between orientations themselves: orientation toward people and orientation toward tasks (Tab. 5). According to results where Sig. (2-tailed 0,879), we concluded that the difference between these orientations is very small. Independent Samples Test was used for investigation of orientation to task and orientation of the people (Tab. 6) according to individual responses to 18 questions. According the research result there are no statistically meaningful differences in responses by school principals.

\section{Discussion}

It is concluded that research problem 1 is not confirmed, which means that there is no statistically important difference in measurement of the school principal regarding the gender. Also, research problem 2 and 3 are not confirmed. It means that there is no statistically important difference in measurement of school principal style - orientation toward people and orientation toward tasks in the group of men and women.

The most interesting results of this research are following:

All questioned principals are team directors (Fig. 1). Research findings show that all principals are placed in quadrant named - team leadership. According to the disposition of results of measurement of school principals leadership styles shown at the picture (Fig. 1) it cannot be concluded that there are differences between men and women regarding management styleleadership style. 


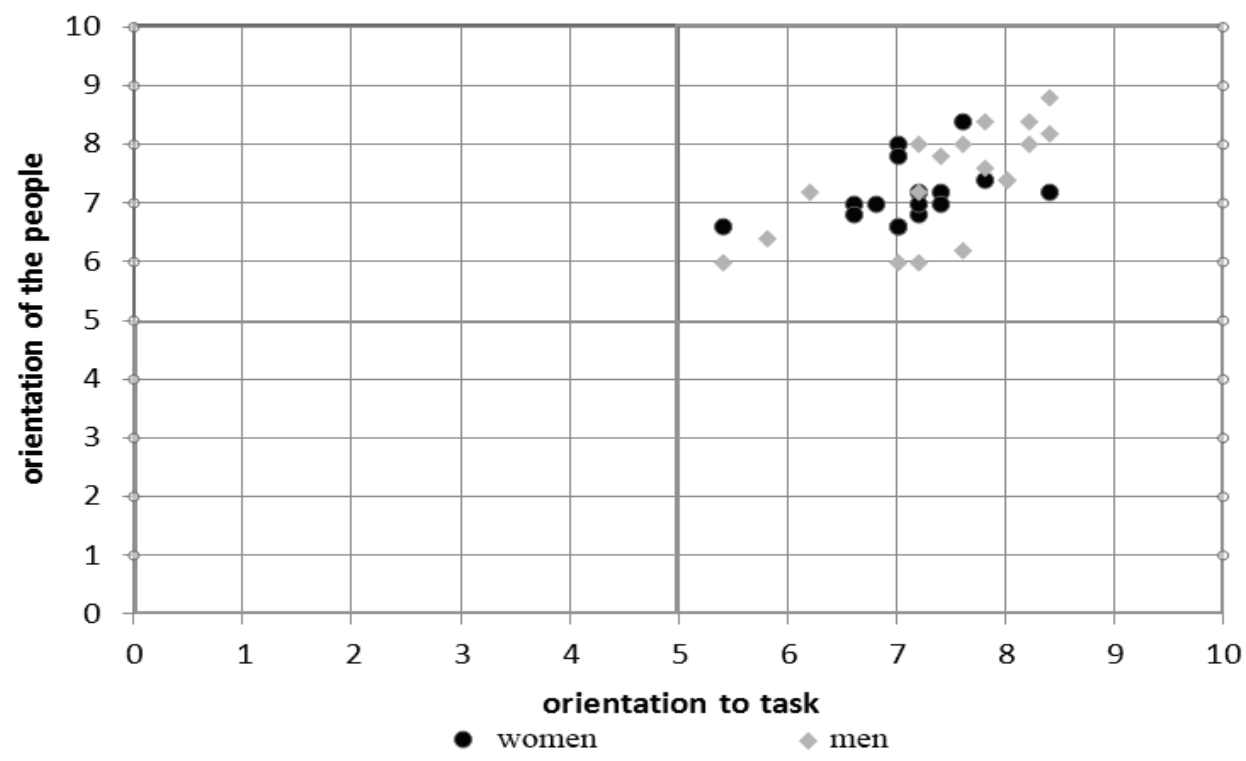

Fig. 1. Style and orientation and gender of the school principal

All questioned principals are equally oriented to people and tasks (table 3). Table shows that different principals from different schools who also differ by gender are equally oriented to concern for people and concern for tasks.

Results show that there is no significant difference between orientations (Tab. 5). It shows that principal uses both orientations in his/her work (to people and task) depending on management needs in the school.

All questioned principals are not significantly different by their answers on 18 questions (Tabs 2 and 6). According to research results, it can be shown that there are no statistically meaningful differences in responses by school principals. No question can be significantly different by its result regarding the gender of the school principal.

There are no significant differences in leadership style among genders. The research shows that there are no statistically meaningful differences between men and women in the selection of management style. Besides the gender, there are some other determinants which affect the management style. Above all, there is an organizational culture.

Similar results in research were obtained by meta-analysis. ${ }^{25}$

25 A. Eagly, I. Carli, The female leadership advantage, p. 807-834. 
$\frac{0}{0}$

\begin{tabular}{|c|c|c|c|c|c|c|c|c|c|c|c|c|c|c|c|}
\hline \multirow{7}{*}{ 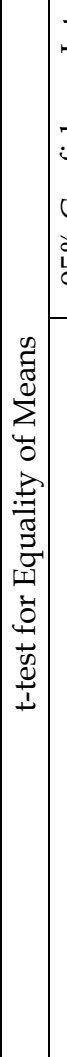 } & $\begin{array}{l}\overrightarrow{\tilde{\nu}} \\
\tilde{a}^{2}\end{array}$ & 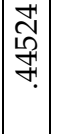 & $\begin{array}{l}\stackrel{\infty}{\infty} \\
\stackrel{7}{7}\end{array}$ & \begin{tabular}{|l}
$\mathbb{N}$ \\
$\mathbb{N}$ \\
0 \\
0
\end{tabular} & 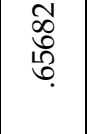 & 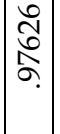 & 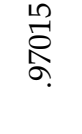 & 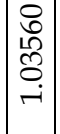 & 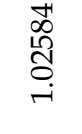 & 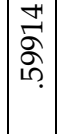 & $\begin{array}{l}\text { Nat } \\
\text { క్ర }\end{array}$ & $\mid \begin{array}{l}0 \\
\tilde{n} \\
\hat{n} \\
0\end{array}$ & $\begin{array}{l}\text { ले } \\
\infty \\
\text { రి. }\end{array}$ & $\begin{array}{l}\overrightarrow{5} \\
0 \\
0 \\
0 \\
0\end{array}$ & ఫ̊ \\
\hline & 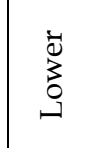 & 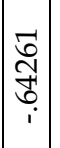 & 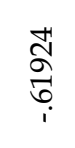 & 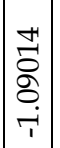 & 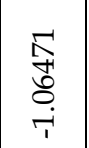 & 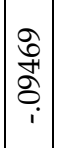 & $\begin{array}{l}\hat{0} \\
\infty \\
\infty \\
0 \\
0 \\
i\end{array}$ & 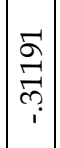 & $\begin{array}{l}0 \\
\text { ठิ } \\
\text { ఝి } \\
i\end{array}$ & 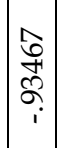 & 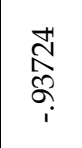 & 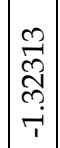 & $\begin{array}{l}\text { 心े } \\
\infty \\
\infty \\
\stackrel{1}{\rightarrow} \\
\stackrel{+}{1}\end{array}$ & 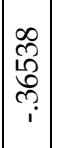 & 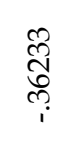 \\
\hline & कृ & $\left|\begin{array}{l}1 \\
\tilde{N} \\
\mathrm{n} \\
\end{array}\right|$ & $\begin{array}{l}\text { 辛 } \\
\text { مै }\end{array}$ & 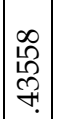 & 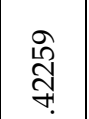 & 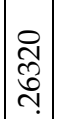 & $\begin{array}{l}\text { 옹 } \\
\text { ำ }\end{array}$ & 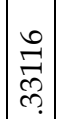 & $\begin{array}{l}\text { त्र } \\
\text { ते }\end{array}$ & 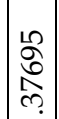 & 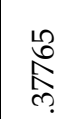 & 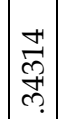 & $\begin{array}{l}\text { f } \\
\text { ते }\end{array}$ & 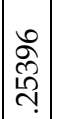 & $\begin{array}{l}\text { त్ } \\
\text { సె }\end{array}$ \\
\hline & $\sum^{\Xi}$ & $\mid \begin{array}{l}\infty \\
\infty \\
\infty \\
\delta \\
0 \\
i\end{array}$ & $\begin{array}{l}\infty \\
\infty \\
\infty \\
\delta_{i}\end{array}$ & 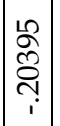 & 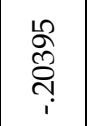 & 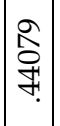 & 突 & 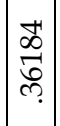 & 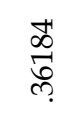 & $\mid \begin{array}{l}0 \\
\hat{N} \\
6 \\
\ddots \\
1\end{array}$ & 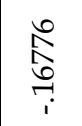 & 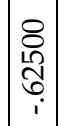 & 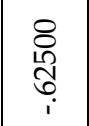 & 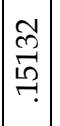 & 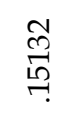 \\
\hline & 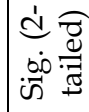 & $\stackrel{+}{i}$ & $\bar{R}$ & 番 & ర్రి & $\begin{array}{l}0 \\
7\end{array}$ & \& & 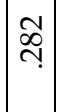 & సै & bิ & . & 文 & ఫ్రి & 总 & 员 \\
\hline & $\vec{t}$ & 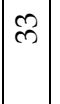 & $\begin{array}{l}\vec{~} \\
\text { ડे } \\
\hat{N}\end{array}$ & $m$ & 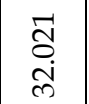 & $m$ & $\begin{array}{l}\infty \\
\text { ळ. } \\
\text { ले }\end{array}$ & $m$ & 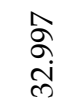 & $m$ & $\begin{array}{l}\text { N } \\
\stackrel{-}{m} \\
\end{array}$ & $m$ & $\begin{array}{l}\hat{\theta} \\
\stackrel{+}{i}\end{array}$ & $\ddot{\infty}$ & $\begin{array}{l}\hat{\widehat{~}} \\
\text { i. } \\
\text { ले }\end{array}$ \\
\hline & + & 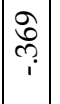 & $\begin{array}{l}\infty \\
\infty \\
i \\
i\end{array}$ & $\mid \begin{array}{l}\infty \\
0 \\
⿱ 1 \\
1 \\
1\end{array}$ & $\begin{array}{c}\infty \\
\stackrel{8}{+} \\
i \\
i\end{array}$ & $\mid \begin{array}{c}10 \\
\hat{\sigma} \\
\stackrel{r}{r}\end{array}$ & تُ & 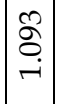 & $\begin{array}{l}\stackrel{8}{\circ} \\
\stackrel{+}{r}\end{array}$ & $\stackrel{8}{7}$ & $\underset{i}{\mathbb{Z}}$ & $\mid \begin{array}{c}\vec{r} \\
\infty \\
\dot{i} \\
\vec{i}\end{array}$ & $\begin{array}{l}\mathbb{H} \\
\stackrel{\mathbb{H}}{+}\end{array}$ & 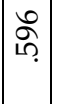 & ళి \\
\hline \multirow{4}{*}{ | } & $\ddot{00}$ & $\begin{array}{l}\infty \\
\vec{m}\end{array}$ & & 8 & & $\begin{array}{l}\mathbb{N} \\
\text { ஸ़่ }\end{array}$ & & $\begin{array}{l}\text { बे } \\
\text { ले }\end{array}$ & & 亲 & & $\ddot{\infty}$ & & $\mid \begin{array}{l}\infty \\
\vdots \\
\infty \\
\infty\end{array}$ & \\
\hline & 工 & $\left|\begin{array}{c}\hat{y} \\
\overrightarrow{-} \\
-\end{array}\right|$ & & 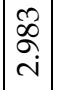 & & $\frac{12}{7}$ & & ָ̀. & & $\stackrel{ }{\circ}$ & & $\begin{array}{l}\overrightarrow{\mathscr{D}} \\
\dot{+} \\
\dot{+}\end{array}$ & & ô. & \\
\hline & & 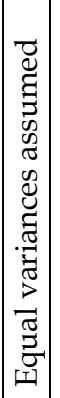 & 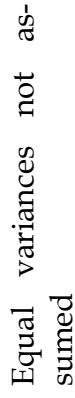 & 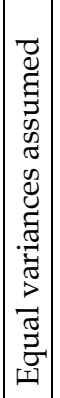 & 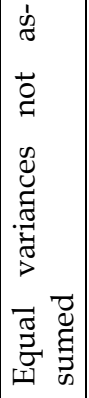 & 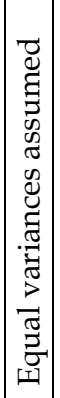 & 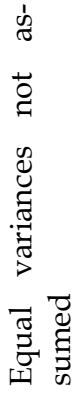 & 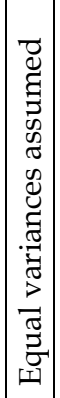 & 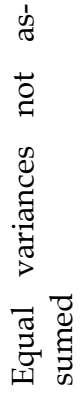 & 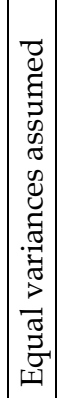 & 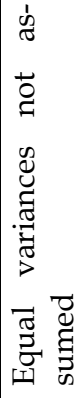 & 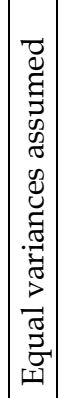 & 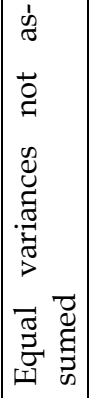 & 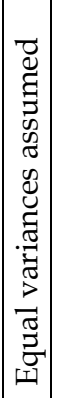 & 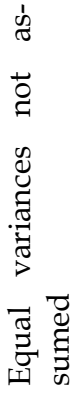 \\
\hline & & & - & & i & & $\dot{m}$ & & $\dot{+}$ & & ம் & & 6 & & $\wedge^{\circ}$ \\
\hline
\end{tabular}




\begin{tabular}{|c|c|c|c|c|c|c|c|c|c|c|c|c|c|c|c|c|c|}
\hline \multirow{7}{*}{ 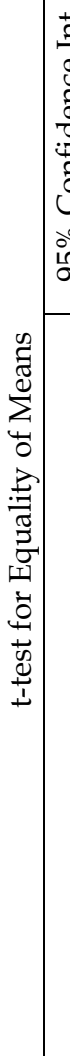 } & 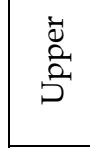 & 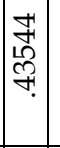 & $\begin{array}{l}\underset{N}{\mathbb{N}} \\
\exists !\end{array}$ & $\begin{array}{l}\infty \\
\infty \\
\infty \\
\infty \\
\sigma \\
\sigma\end{array}$ & $\begin{array}{l}\text { ठ゙ } \\
\text { ठे }\end{array}$ & 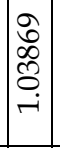 & 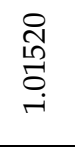 & 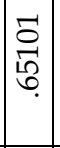 & 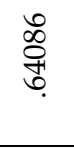 & 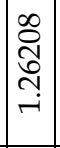 & $\begin{array}{l}\text { م్ } \\
\text { స్ } \\
\text { - }\end{array}$ & $\begin{array}{l}\vec{b} \\
\hat{\infty} \\
\end{array}$ & 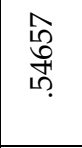 & 辛 & $\begin{array}{l}\text { त్ } \\
\text { ळे } \\
\text { ले }\end{array}$ & 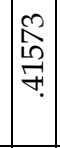 & $\begin{array}{l}\triangleright \\
\stackrel{8}{+} \\
f\end{array}$ \\
\hline & 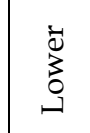 & 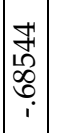 & $\begin{array}{l}\underset{\mathbb{N}}{\mathbb{S}} \\
\stackrel{0}{0} \\
i\end{array}$ & 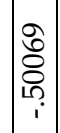 & 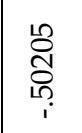 & 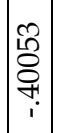 & 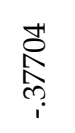 & 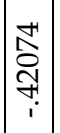 & $\begin{array}{l}8 \\
\stackrel{8}{0} \\
\underset{1}{7}\end{array}$ & $\mid \begin{array}{l}\infty \\
\vec{\infty} \\
\infty \\
\stackrel{0}{i} \\
i\end{array}$ & 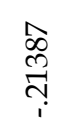 & 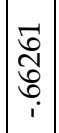 & 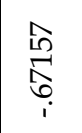 & $\left|\begin{array}{c}0 \\
0 \\
\vdots \\
6 \\
i \\
i\end{array}\right|$ & $\begin{array}{l}\text { 와 } \\
8 \\
10 \\
0 \\
i\end{array}$ & $\begin{array}{c}\infty \\
0 \\
0 \\
\infty \\
\infty \\
1 \\
1\end{array}$ & 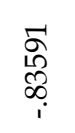 \\
\hline & के & $\begin{array}{l}\hat{f} \\
\text { 今ે } \\
\text { సิ }\end{array}$ & $\begin{array}{l}\text { 人ิ } \\
\text { 워ํ }\end{array}$ & 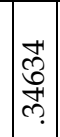 & 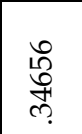 & $\mid$ & 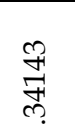 & $\mid \begin{array}{l}\text { ले } \\
\widetilde{ర} \\
\text { }\end{array}$ & $\begin{array}{l}\text { के } \\
\infty \\
\stackrel{\infty}{\Upsilon 1}\end{array}$ & 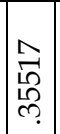 & 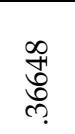 & ‡ & 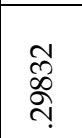 & 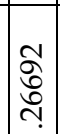 & $\begin{array}{l}\hat{\sigma} \\
\text { مิ }\end{array}$ & 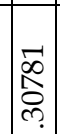 & $\begin{array}{l}\text { Iี } \\
\text { 今े }\end{array}$ \\
\hline & $\sum^{\Xi}$ & 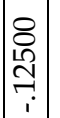 & $\begin{array}{l}\stackrel{8}{\stackrel{\overbrace{}}{7}} \\
\text { ㄱ. }\end{array}$ & 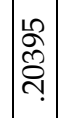 & 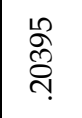 & 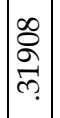 & $\begin{array}{l}\stackrel{\infty}{\circ} \\
\stackrel{े}{~}\end{array}$ & $\left|\begin{array}{c}0 \\
\vec{n} \\
\vec{F}\end{array}\right|$ & $\begin{array}{l}\stackrel{m}{\vec{n}} \\
\vec{\sigma}\end{array}$ & 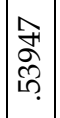 & $\begin{array}{l}\text { f } \\
\text { ले }\end{array}$ & $\mid \begin{array}{l}0 \\
\stackrel{1}{0} \\
0 \\
0 \\
i\end{array}$ & $\begin{array}{l}\text { م્ } \\
\text { ర్రి } \\
\text { i. }\end{array}$ & 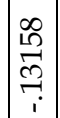 & $\begin{array}{l}\infty \\
\stackrel{\infty}{n} \\
\stackrel{n}{n} \\
\rightarrow\end{array}$ & 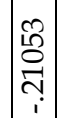 & $\begin{array}{l}\text { ֶి } \\
\stackrel{0}{7} \\
i 1\end{array}$ \\
\hline & 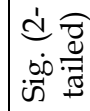 & 茴 & Iี & $\begin{array}{l}8 \\
\text { டி }\end{array}$ & 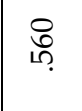 & 吾 & 命 & | & ถి. & $\begin{array}{l}\infty \\
\stackrel{\infty}{\oplus} \\
\uparrow\end{array}$ & ณ̂ & $\begin{array}{l}\infty \\
\infty \\
\infty \\
\infty\end{array}$ & $\begin{array}{l}10 \\
\infty \\
\infty\end{array}$ & م్రి & $\stackrel{10}{0}$ & वे & $\begin{array}{l}\infty \\
\text { f }\end{array}$ \\
\hline & tै & ल & 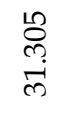 & $\ddot{m}$ & $\begin{array}{l}\stackrel{H}{\sigma} \\
\vec{m}\end{array}$ & $m$ & 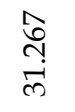 & $\stackrel{m}{m}$ & $\begin{array}{l}\infty \\
\widetilde{\Omega} \\
\text { } \\
\infty\end{array}$ & $m$ & 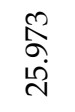 & $\ddot{c}$ & 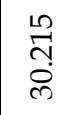 & $\stackrel{m}{m}$ & $\begin{array}{l}\text { ปี } \\
\text { ते } \\
\text { ल }\end{array}$ & $\stackrel{m}{m}$ & $\begin{array}{l}\hat{N} \\
\stackrel{N}{N} \\
\text { ले }\end{array}$ \\
\hline & + & | & 尽 & $\begin{array}{l}\infty \\
\not \\
\llcorner\end{array}$ & 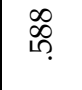 & ఠิ & $\stackrel{4}{\sigma}$ & क्ञ & 过 & 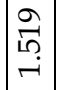 & 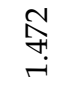 & 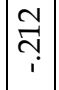 & $\stackrel{\text { }}{\text { †े }}$ & gृ & $\begin{array}{l}\infty \\
\stackrel{0}{\circ} \\
i \\
i\end{array}$ & $\begin{array}{c}+1 \\
0 \\
0 \\
i \\
i\end{array}$ & $\begin{array}{l}10 \\
0 \\
i \\
i\end{array}$ \\
\hline \multirow{2}{*}{ 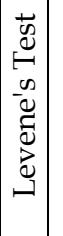 } & $\ddot{\omega}$ & 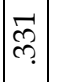 & & ఫે & & ? & & 文 & & 拿. & & ถి. & & ते & & 趛 & \\
\hline & 山 & 令 & & छ゙. & & $\begin{array}{l}8 \\
\stackrel{1}{ } \\
\mathrm{i}\end{array}$ & & 总 & & \begin{tabular}{|c} 
के \\
$\tilde{\omega}$ \\
$\tilde{\infty}$
\end{tabular} & & 点 & & 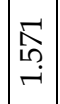 & & શิ & \\
\hline & & 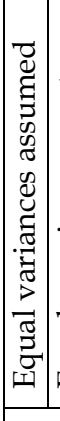 & 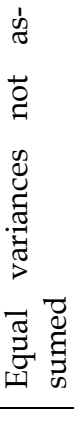 & 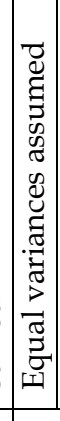 & 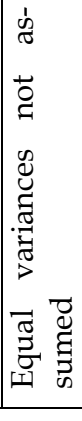 & 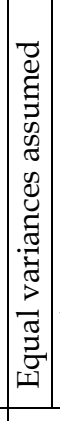 & 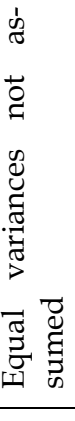 & 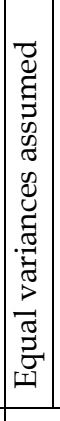 & 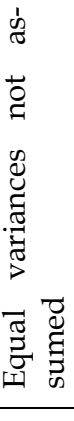 & 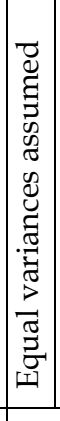 & 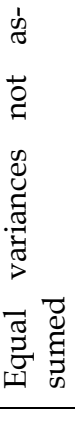 & 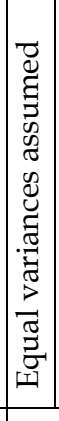 & 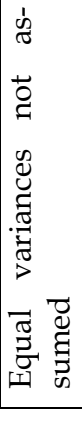 & 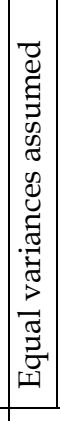 & 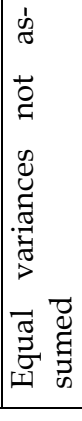 & 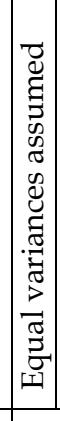 & 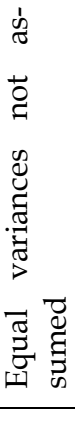 \\
\hline & & $\infty \infty^{\circ}$ & & & $\sigma^{\circ}$ & & $\dot{9}$ & & $\dot{F}$ & & & & $\ddot{\vec{r}}$ & & $\dot{+}$ & & வி \\
\hline
\end{tabular}




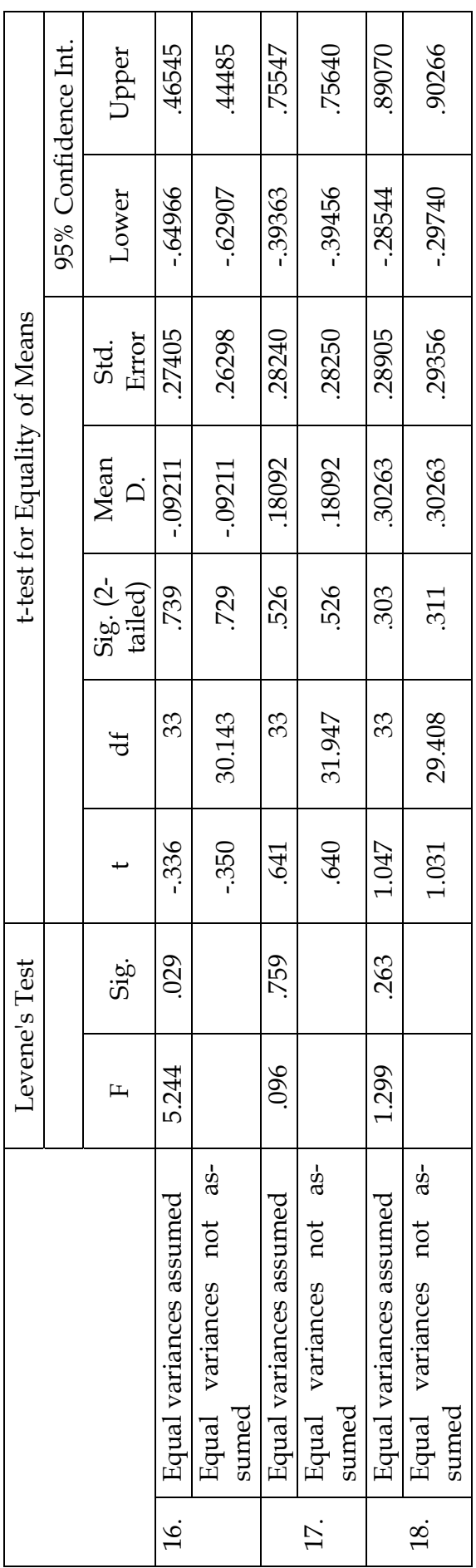


There are two important limitations of the study. First, there is not literature that deals with this issue in Serbian schools. In Serbia were not done the research on gender and management/leader styles in school. Second, the uniqueness of each school culture complicates research. Each school has its culture, which is very different from the culture of other schools.

\section{Conclusion}

Results in this research showed that there are no differences in management styles of school principals regarding gender. School principals, as it is presented in Blake managerial network, showed that they belong to a team management with good balanced combination of orientation toward people and orientation toward tasks. These principals give the positive example and intend to promote team atmosphere where all employees will be able to reach the highest potential as team members and people. They encourage teachers to be more efficient in achieving their goals. Team directors constantly foster connections between employees. They like to delegate businesses and to create productive teams. Principals understand that it is important to use advantages of differences. It is important to develop leadership styles in order to make them more adaptable to the work of the school. On the other hand, school needs to create conditions in which everyone can achieve his/her maximum, despite differences.

The relationship between genders and management style is full of paradoxes, because there are some questions without answers. Each research gives precise answers, but some new questions always seem. It proves that this subject is an endless process in which complex combinations of relationship between genders and environment appear. Current evidences show that there are certain small differences between genders, but they are mostly under the influence of different socialization. Differences between genders are under the influences of stereotypes which increasingly create place for a rational view, where men and women accomplish their tasks by selecting the management style which will not depend on gender, but on the kind of a task.

\section{BIBLIOGRAPHY}

Appelbaum S., Audet L., Miller J., Gender and Leadership? Leadership and Gender? A Journey Through The Landscape of Theories, Leadership and Organization Development Journal, 2003, 24, 1 . 
Blake R., Mouton J., The Managerial Grid, Gulf Publishing Company, Houston 1964.

Blake R., Mouton J., The new managerial Grid, GPC, Houston 1978.

Blake R., Mouton J., The Managerial Grid III, Gulf Publishing Company, Houston 1985.

Blake R., McCanse A., Leadership dilemmas: Grid solution, TX:GPC, Houston 1991.

Book E., Why the best man for the job is a woman, Harper Collins, New York 2000.

Chemers M.M., Watson C.B., May S.T., Dispositional affect and leadership effectiveness: a comparison of self-esteem, optimism, and efficacy, Personality and Social Psychology Bulletin, 2000, 26 (3).

De Zárate R.O., Women rulers currently in office, 2007, from http://www.terra.es/ personal2/ monolith/00women5.htm [retrieved: 20.07.2014].

Eagly A., Achieving relational authenticity in leadership: Does gender matter? Leadership Quarterly, 2005, 16.

Eagly A., Carli I., The female leadership advantage: An evaluation of the evidence, Leadership Quarterly, 2003, 14.

Engen M., Willemsen T., Gender and leadership styles: a review of the post decade, Tilburg University Press, Tilburg 2000.

Engen M., Leeden R., Willemsen T., Gender, context and leadership styles: A field study, Journal of Occupational and Organizational Psychology, 2001, 74.

Hymowitz C., In the lead: Women tell women: Life in the top jobs is worth the effort, Wall Street Journal, 2006, November 20, B1.

Judge T., Bono J., Ilies R., Gerhardt M., Personality and leadership: A qualitative and quantitative review, Journal of Applied Psychology, 2002, 87.

Kennard J., The differences between male and female, 2012 from: http://www. trainingzone.co.uk/user/85621 [retrieved: 20.07.2014].

Northouse P., Liderstvo teorija i praksa, IV izdanje, Data Status, Beograd 2008.

Olid C., Models of Professional Career of the Managerial Woman, Universitas Psychologica, 2013, 12 (4), p. 1237-1254. Doi: 10.11144/Javeriana.UPSY12-4.mopc

Powell G., Graves L., Vomen and men in management, CA: Sage, Thousand Oaks 2003.

Robbins P., Coutler M., Management, Datastatus, Belgrade 2005.

Taniguchi H., Gender Differences in the Effect of Employment and Family Characteristics, Nonprofit and Voluntary Sector Quarterly, 2006, 35, 1.

Veccio R., Leadership and gender advantage, Leadership Quarterly, 2002, 13.

Warrell M., Can Women Do More To Make Their Way To The top? 2011, from: www.forbes.com/... / womensmedia/.../can-women [retrieved: 20.07.2014]. 